\title{
Aleksandra Litawa, Chór amatorski jako forma edukacji kulturalnej dorosłych na przykładzie krakowskich zespołów chóralnych, „Prace Monograficzne 760”, Wydawnictwo Naukowe Uniwersytetu Pedagogicznego, Kraków 2016, ss. 162, tab., wykr., bibliogr.
}

Już na samym początku monografii Autorka zauważa, że „o współczesnych chórach nieprofesjonalnych skupiających ludzi dorosłych wiadomo niewiele" (s. 5). Jako osoba od ponad czterech dekad związana z amatorskim ruchem śpiewaczym w naszym kraju muszę niestety potwierdzić słuszność tej uwagi. Współcześnie niemal nie pojawiają się publikacje ukazujące w sposób całościowy - pogłębiony i wieloaspektowy - społeczną aktywność artystyczno-kulturalną związaną ze wspólnym zespołowym śpiewaniem w skali ogólnopolskiej, w danym mieście czy w regionie. $Z$ rzadka znaleźć można jedynie mniej czy bardziej udane próby opracowania dziejów jakiegoś chóru, pisywane pro domo sua/ „ku pamięci” przy okazji jakiegoś jubileuszu danego środowiska, najpewniej przez jakiegoś zaangażowanego chórzystę-działacza lub osobę z najbliższego kręgu przyjaciół zespołu. Od lat nie spełnia już swojej dawnej roli także Polski Związek Chórów i Orkiestr, który wcześniej przez dziesięciolecia sprawował merytoryczną i organizacyjną opiekę nad zdecydowaną większością polskich chórów amatorskich (nurtu świeckiego) dając tym samym potencjalnym badaczom rodzimej chóralistyki m.in. możliwość uzyskiwania danych nt. stanu ilościowego amatorskiego ruchu chóralnego (liczby zespołów, ich stanu osobowego, stażu śpiewaczego poszczególnych chórzystów, etc.) w całym kraju, jak i w poszczególnych regionach (oddziałach wojewódzkich) oraz aktywności artystycznej poszczególnych zespołów śpiewaczych (repertuaru, koncertów, nagród zdobytych na regionalnych, krajowych czy zagranicznych przeglądach, festiwalach i konkursach, etc.). Takich informacji nie posiadają też dzisiaj ani Narodowe Centrum Kultury (czy jego wojewódzkie odpowiedniki), ani Departament Szkolnictwa Artystycznego i Edukacji Kulturalnej MKiDzN. 
Tak więc badacz podejmujący problematykę edukacji kulturalnej dorosłych poprzez uczestnictwo w pracy amatorskiego chóru, zespołu wokalno-instrumentalnego czy orkiestry staje już na początku swej pracy badawczej przed wyzwaniami związanymi z odpowiednim doborem próby badawczej oraz możliwościami odniesienia swych zamierzeń badawczych - a później także wyników badań i wniosków z nich płynących - do ustaleń poczynionych we wcześniejszych opracowaniach, gdyż takowych od wielu lat nie było (por. podrozdział II.2 pt. „Stan dotychczasowych badań nad chórami amatorskimi" - s. 31-34).

W kontekście powyższych uwag można zatem z uznaniem przyjąć fakt, iż Aleksandra Litawa „odważyła się” na podjęcie trudu przygotowania monograficznego opracowania tytułowej problematyki. Uczyniła to na bazie materiału badawczego zebranego aż w siedemnastu amatorskich chórach miasta Krakowa (świeckich środowiskowych, świeckich akademickich i parafialnych). Dzięki temu czytelnicy otrzymali interesujący poznawczo materiał empiryczny, dotyczący środowiska krakowskiego, a potencjalni badacze amatorskiego ruchu kulturalno-artystycznego w innych miastach/ regionach Polski ciekawy i wielowątkowy materiał porównawczy dla swych przyszłych prac badawczych, a także - gdyby zechcieli i z tej "podpowiedzi” skorzystać - wskazówki dotyczące jednego z możliwych podejść metodologicznych w badaniach nad amatorskim ruchem artystycznym, o tyle ciekawe, iż sprawdzone w „badawczym boju” przez Autorkę monografii (por. rozdział III, s. 42-58).

Ze względu na szczupłość miejsca wskażmy jedynie główne kategorie, w obrębie których A. Litawa poprowadziła swoje analizy krakowskich chórów. Są nimi:

I. Geneza i rozwój organizacyjny zespołów;

II. Cele, formy i metody pracy;

III. Kwestie programowe (w tym repertuar);

IV. Baza lokalowa, wyposażenie;

V. Warsztat zawodowy i kompetencje społeczne dyrygentów;

VI.Charakterystyka społeczna, wiekowa i wymagania wobec chórzystów;

VII. Motywy uczestnictwa w pracy chóru;

VIII. Korzyści z członkostwa w opiniach śpiewaków.

Jak więc widać, autorka poruszyła w monografii wiele różnorodnych wątków odnosząc się tym samym do najbardziej istotnych komponentów środowiska społecznej krakowskiej chóralistyki i dostrzeżonych w niej wartości kształcących i aspektów wychowawczych. 
Warto na zakończenie niniejszego krótkiego omówienia nowej publikacji A. Litawy przywołać jeden z wniosków zawartych w podsumowaniu:

„Uczestnictwo osób dorosłych w amatorskim zespole chóralnym wiąże się z ich wszechstronnym rozwojem. Chór nie tylko uczy, ale też wychowuje. Zaangażowanie śpiewaków w działalność artystyczną prowadzi do uzyskania przez nich określonych efektów poznawczych, kształcących i wychowawczych. Wartości, których nośnikiem jest zespół, stają się inspiracją do pogłębienia związku z kulturą, prowadzą do wykształcenia pewnej postawy aksjologicznej, która towarzyszy chórzystom również na innych płaszczyznach życia" (s. 147).

Wydaje się, że ta sformułowana przez Autorkę na kanwie jej badań nad amatorskim ruchem chóralnym $\mathrm{m}$. Krakowa uwaga mogłaby znaleźć potwierdzenie we wszystkich innych środowiskach, w których mamy do czynienia z dobrowolnym, świadomym uczestnictwem osób dorosłych w zorganizowanej działalności artystycznej o charakterze hobbystycznym.

Zapraszam do lektury.

Tomasz Maliszewski 